\title{
Democracy is on exile. Facing the challenge of neoliberal authoritarianism: an interview with professor Henry Giroux*
}

\author{
Gustavo de Oliveira Figueiredo' (DD \\ Vera Helena Ferraz de Siqueira' (D)
}

\section{BRIEF INTRODUCTION}

This paper is presented in the format of a dialogue. The interview with Dr. Henry Giroux took place on September $7^{\text {th }}, 2018$ in Hamilton, Ontario, Canada, in his office at the Department of Cultural Studies, where he currently holds the Chair for Scholarship in the Public Interest and Paulo Freire distinguished scholar in critical pedagogy at the Department of Cultural Studies from McMaster University. Both authors who have prepared the interview are professors at the Federal University of Rio de Janeiro (Universidade Federal do Rio de Janeiro - UFRJ).

\section{THE INTERVIEW ${ }^{1}$}

I - Professor Giroux, thank you for the opportunity to interview you today. It is a pleasure and a great honor to tap into your ideas on education, and political and social issues.

HG - I'm delighted and honored that you're here, and I'm more than willing to be able to participate in this interview with the hopes that it will be helpful.

I - Based on your academic experience, which are the most important ideas to address the current threat to democracy our societies currently face?

HG - I came into this field, cultural studies in education, just in the 1970s, when I started to work at the university. Before that, I had been a high school teacher, which was very informative for me. At that time, I didn't have the theoretical

1 I: stands for Interviewers; and HG: for Henry Giroux.

\footnotetext{
*Sponsored by the Institutional Program for Internationalization (Programa Institucional de Internacionalização - PrInt) of Coordination of Superior Level Staff Improvement (Coordenação de Aperfeiçoamento de Pessoal de Nível Superior - CAPES), Brazil. 'Universidade Federal do Rio de Janeiro, Rio de Janeiro, RJ, Brazil.
} 
experience or the background to be able to understand the approaches to teaching that I was using, even though I considered them to be very progressive. I would use progressive radical films, I would engage the kids in seminars and talk to them in an informal way, but at the time I was under attack, by the vice principal, who wanted me to organize my classroom in a military-style approach, put the students in rows and have them memorize classroom material. I was a social studies teacher. And at the time, I really didn't have the language to be able to explain theoretically what I was doing, and be able to legitimately justify my pedagogical practices. Ironically, that week I was given a copy of Pedagogy of the oppressed (Freire, 1983), and I went home, started reading the book and... It changed my life, I mean; it gave me a language that says, among other things, that experience has to take a detour through theory, that's where you began. And I think, in many ways, that was the beginning of my vocation as somebody who believes that education has to be related to social change, that education has to take into consideration the cultures and histories of the students that you deal with, that education has to be always attuned to matters of context, history, culture, and the voices of the students we engage.

The first work that I started doing in the 1970s was in the aftermath of two very important currents of work that were going on in different places. There was the new sociology of education in Britain, in which they were looking at the relationship between culture, power, and knowledge, utilizing Gramsci along with theorists such as Althusser, Bourdieu... At the same time, reproduction theory was taking hold in the United States, which argued that schools were political and social states that they struggled over, but they were largely modeled after dominant sites of repression such as prisons. My first entry into both of these theoretical positions was to challenge them, and to argue that if you simply assign power, if you're up to the assumption that power only equates to domination, then it's impossible to theorize any notion of resistance. So, I started off trying to understand theories of resistance in ways that Paul Willis (1977) had talked about in Learning to labor, and I wanted to develop it further. I operated on the assumption that you have to create something meaningful to make it critical, to make it transformative. And that's where the language of critique and possibility really had its roots in that initial type of 1970s intervention; this work took place when reproductive theory was heavily criticizing what might be called the then-existing culture of positivism that was shaping mainstream educational thought and practice the United States! Empiricism was in the air, right? And the language of metrics was gaining strength in education, particularly because, starting in the 1980 s, education was then basically seen as work-related, and defined largely as a form of training. It was a space where you trained people for the workplace. And I wanted to challenge that position... it was really a terrible time for theorizing and trying to imagine education as being a democratic public sphere, as opposed to a workstation that served the interests of capital.

\section{I - Changing was not a possibility?}

HG - Oh, no! It wasn't about change, it was basically about reproduction. From there, I moved out of theories of resistance into looking at schools more realistically, trying to understand basically what it would mean to draw from a whole 
range of theories to really articulate a more democratic conception of education, particularly schooling. And there, my work began to hook up, with people like Stanley Aronowitz. Stanley Aronowitz and I wrote books on theories of reproduction and resistance, and tried to further that discourse. My next move was to talk about teachers as public intellectuals (Giroux, 1988).

\section{I - Based on Gramsci?}

HG - Based on Gramsci. Based on the notion that all politics is a form of education, which Gramsci was certain. And also based on the work of Bourdieu, I mean, although I heavily criticized Bourdieu, cause I thought his position was too structuralist for me, I became very mesmerized with the work of Raymond Williams at the time, I was deeply embedded to Althusser, I thought that was interesting work. But I was heavily influenced by Gramsci, and... moving into that kind of discourse in which I was talking about teachers as public intellectuals, I really was trying to theorize a notion of teachers that would suggest they would have some control over the conditions of their own labor... Coupled with a vision about what schools could possibly be that in some way contributed to the logic of social order. I never took the position that schools would save society. I said schools had an obligation to educate students who could go out and work politically to do everything they can to make democracy all the more meaningful, all the more central, and all the more a necessity to struggle over. That was the point, right?

\section{I - Yes...}

HG - Then I became interested in cultural studies. And I was trying to understand why cultural studies were not heavily involved with the work of pedagogy. It just seemed so obvious to me, because cultural studies emerged from works about education. I mean, what is it, it's an adult education. And this is where all cultural studies began, but it went instead to high theory. And so, suddenly, I was one of the first people to introduce questions of pedagogy into cultural studies. In the 1990s, cultural studies theorists, like Larry Grossberg were always supportive of my work. I have published one of the first issues of cultural studies in pedagogy (Giroux, 2007). At the same time, as I moved into other disciplines talking about pedagogy, I was writing about border pedagogy. That became a term where people had to travel across boundaries, not just think about education as something to do with schooling, making a distinction between education and schooling, so that we could see how education was sent to other spheres. I mean, a lot of people in communication were writing about this, but I wanted to expand the boundaries of these discourses... Stanley Aronowitz and I, in the midst of the debate on postmodernism in 1992, were trying to, in some way, incorporate some of that language, the argument against master narratives, like the notion that things had to be understood relationally, without buying the whole spiel of postmodernism regarding a kind of postmodern relativism. And we were terribly attacked over that intervention.I think the biggest mistake I ever made in publishing was publishing a book with the title Postmodern education, because it seemed to suggest that we were buying the theory in its entirety in all of its various versions, and we weren't. We were really holding it 
up as a way to interrogate, and to try and figure out what it basically had to offer us. From there, I got very concerned about the crisis of youth, because it seemed to me that the left was talking a lot about economic structures, they were talking a lot about other issues, but they weren't talking about young people. And I couldn't understand that. I wrote a number of books at that time, probably five or six, about the war in youth. The best reference would be Youth in a suspect society (Giroux, 2009), in my estimation. And from there, of course, I became enormously concerned about the rise of fascism and authoritarianism, and what it meant to develop an educational discourse that would address that stuff. I had been writing about neoliberalism I'd say, and authoritarianism, for the last ten years, but also writing about higher education (Giroux, 2014), and public policies in education, and trying, increasingly, to make my language more accessible. Hence, I moved from being an academic in the strict sense of the term to being a public intellectual, by which my work would be rigorous and accessible at the same time and address a much broader audience. And that's probably the endpoint of where I am at this stage of my writing and scholarship.

I - Brazil only escaped the grip of dictatorship in 1985 and presently its democracy is under severe attack. These are some major signs that, as you would say, currently "democracy is on exile" in Brazil, and the same situation is true for other Latin American countries. How would you explain this decadence of representative democracies around the world and what is the potential of political struggles for a radical democracy? Do you believe a new type of activism could arise to fight against this far-right wave that is crushing democracy and human rights?

HG - I think that one of the things that we're seeing all over the world is the rise of a kind of right-wing populism that merges the elements of White supremacy with the fear and anxiety that comes out of a new global order that is based on productivity and the constant mobilization of wealth offered to the one percent. And I think that where there is a high degree of right-wing propaganda which is aimed at preventing them from understanding the systemic nature of the problems they face daily, there is ample room on the part of tyrants to trade simply on their anger and fears, particularly a fear of the other. This kind of fear can be hijacked into support for the strong men with simple answers. Once this happens, you begin to see how the tide of fascism emerges in different historical moments and settings right now. Global capitalism has basically destroyed the foundations for democracy all over the world. You can't have a world, in which 1\% of people control all of the rest of the world, sorry, it doesn't work, you know? You can't have a world where ideas matter when the institutions that support those ideas are defunded or under siege, as they are in Hungary, and as they are in Poland, and as they are in some cases in Latin America. You can't have a democracy when the languages of hate, bigotry, sexism, hatred of gays, hatred of sexual rights, of women's rights become normalized. It doesn't work.

I think that one of the ways in which we see this being formed, one of the things that we see happening all over the world, actually, is that there's a need to redefine politics for the new era, and it suggests that there has to be a massive change in consciousness about the power that people might have collectively rather than individually, to be able to move together, and to not just rely on unions, but to rely 
on social movements. These movements have to come from the bottom. We can no longer rely on established politicians for the kinds of political and social movements that basically are going to present a real threat to the established power. But I don't think anything is going to happen unless we take this matter of education seriously, and educate people at local levels about the power they might have, the conditions in which they find themselves, how they can struggle, and what it means to work collectively as you've been doing with your own work, with other people, to be able to be part of a collective, that can then be part of a collective that operates at three levels: at the local, the national, and the international levels. This is an international fight. This is not just a fight that's going to take place within national boundaries, like viruses... Viruses cross boundaries, they don't recognize states anymore. Global capital does not recognize nation-states; they don't care about nation-states. Power, as my friend Zygmunt Bauman used to say, is now separated from politics. Politics is local; politics refers to the ways in which you identify problems. Power is the means to address them. The people that have wealth have the power to address them. They're not addressing them! They don't care about climate change, they don't care about the increasing poverty in the world, they don't care about the fact that, within a short period of time, 40 to $50 \%$ of people - because of the revolution in technology and robotics or because of the constant movement of labor, technology — will not have jobs. They don't care about basic needs. Basic needs! We're talking about a new conception of time under capitalism. Time is a luxury for the very few, the ruling classes and a deprivation for the 99\%. Let's be realistic in recognizing that is the vocabulary of war! You cannot have that kind of power concentrated in so few hands and not recognize the need to fight back with multiple forms of resistance... educational, political, social, and cultural. I mean, first, we create what we call the democracies in exile. In addition, there is a need to revive the general strike, a tactic that proved very successful recently in Hong Kong and was used by labor at the beginning of the twentieth century.

\section{I - This metaphor is really important right now.}

HG - This metaphor is enormously important! Because we have to be able to make visible what a democracy looks like within fascist politics. The concept of exile, for instance, is both symbolic and real, as it makes it clear that in capitalist countries today most people are marked for terminal exclusion by virtue of their race, class, ethnicity, and religion. In our minds, it's one thing, but in reality, it means something else. As a project and movement, it has to be a model for what a democracy would look like at a level in which you can acknowledge that people can share, that they can be compassionate, that they can provide health care. I've always thought it amazing that when you look at the evangelical churches in the United States... They're not just churches, they're also daycare centers, they are also health clinics, right? They also provide picnics, and you look at what the Nazis did with the workers' movement, the movement of the masses, right? Workers, in the 1930s, picnics, parades, and theater, in other words culture, became a crucial source of inquiry, central to politics itself. Put differently, Politics follows culture. People don't live ideologies, they live in cultures. Ideologies give shape to their cultural experiences. 
Culture is the space where individuals live with their bodies and the desire to address their most basic needs, right? I mean, they're constrained by all kinds of forces so that you can never talk about choice without talking about constraints. People who are suffering have a lot of constraints and few choices; people who do not suffer have few constraints and lots of choices. That's the power of capital! That's the power of wealth, that's what wealth does. When you divide it, when you establish it, when it only benefits a few people, then time becomes your enemy. And, what does it mean for time to be a resource and to be your friend? And does it mean time to serve you rather than time serving other people? We're not only just talking about Marx's old notion of exploitation, we're now talking about disposability (Giroux, 2015); we're now talking about entire populations. When time is a luxury rather than a deprivation, people can develop a range of capacities that enable them to be in control of their lives, experience happiness, and develop compassion for others. When it is a deprivation, the agency is enormously constrained and is largely devoted to simply surviving, getting by so as not to starve, die, or simply stay alive.

And the previous question you asked me, what I forgot to mention was one of the things that I had been pushing for a long time, is the importance in neoliberal times of the politics of disposability. Capitalism now is no longer simply about the old Marxist notion of exploitation. Now you have a logic of disposability that actually becomes a central feature of capitalism itself as more and more groups are considered redundant, by virtue of not being plugged into the economy, by virtue of their race, by virtue of their sexual orientation, by virtue of their religion, by virtue of the countries they come from, by virtue of any other category that doesn't mirror what seems to be a white nationalist, white supremacist understanding of what the world should look like, how the nation-state should be configured. Disposability means that some people are considered unknowable, voiceless, invisible, and considered excessive or, even worse, as threats and enemies of a society.

But I think that in terms of the last question, as grim as that all sounds, you have a generation like yours who are not willing to put up with these forms of domination in these times when capitalism is global. They don't buy the racism, the hatred, the massive iniquitous distribution of wealth and power. They're cosmopolitan, their sexualities are more fluid, they're border crossers, they have an enormous, an immense understanding of the technologies... And they're more compassionate in many ways. And I think that for a generation that has been written out of the script of democracy and has seen their future canceled, they are unwilling to sit back passively and accept the violence waged against them. They won't tolerate it anymore, you know? And I think we're seeing young people who are looking at these Nazi movements, the rise of state violence, and the assault on all vestiges of democracy and are saying with their words and bodies that they have had enough. All over the globe, democracy is under siege. In Hungary, the United States, Turkey and, of course, in Brazil, with all the neo-fascism prototype. The thugs who run these countries are increasingly emboldened by Trump. But, what does that mean? It means that if I believe I'm a racist, a bigot, if I support the one percent, eliminate social provisions, hate Muslims, believe in a notion of racial superiority, that's what that means! These demagogues are saying to the people that if you want a government on the side of fascism, it is 
not only okay, but you should wear your ideology as a badge of honor. The message here feeding a reactionary populism is: "Look, I'm sorry, I'm a fascist, that's why I'm going to vote for this guy!". These are dangerous times and the dividing line today is no longer between one version of democracy or another, the dividing line today, in many of these countries, is between democracy and fascism. That's what is different about the current historical moment. The choice today in many countries is between a democracy that supports the social contract and a fascism that doesn't. Unreal! It's polarizing, but only because we're not dealing with different dimensions of democracy, we're not talking about radical democracy versus liberal democracy versus a kind of conservative understanding of democracy, right? We're dealing with fascism in one hand, and all those versions of democracy on the other. That's a dividing line.

I - In this scenario, what are the spaces of resistance, of militant hope? What would you say to Latin America researchers, professors, teachers, students, and community leaders that could have access to this interview and your ideas, to give them some hope in these dark times?

HG - I would start by saying a couple of things. I would say that we need to take Marx seriously and as he said, history is always open. That's where you want to begin. Even in the midst of the darkest times, people have resisted. Even in the Nazi concentration camps, there was some form of resistance, right? And I think you can never give up on resistance, and you can never give up on hope. Without hope, there is no sense of critical agency, and without an empowered sense of agency, there is no sense of hope. Of course, I am not referring to an empty Disney fied version of hope, a sort of high in the pie in the sky understanding that things will simply work out in the end. This is a notion of hope that lacks a sense of struggle and a sense of the real problems that need to be addressed in the midst of such a struggle. Hope becomes a way of assessing the world that we live in through a lens that is realistic as it is rigorous and brave. You can't have hope without courage. You can't have hope without a degree of understanding, and you can't have hope if you don't engage in collective struggles. You have to engage in resistance collectively, you know? So you need knowledge, you need to be disciplined, to study, and to be focused. You have a sense of history, you think relationally so you can put problems in a context, and you need to work with other people. And you need to believe that in those collective organizations, you can make a change, you know, you can change things for the better.

And I think that one of the things that we all have to realize is we all have talents that are different, and we need to use those talents in the best way we can in order to make a difference. Put differently, we need to intervene in struggles through the skills and knowledge we bring to such struggles. Some people are writers, some people are great union organizers, some people are great in the classroom, and also, some people are great artists who can move people with their poetry, and novels, and articles. And I think we need to recognize that in that cacophony, in that web of difference, we need to find shared understandings of how we can use those differences to create unity around the politics in which we engage. And that unity is around radical democracy. We need an umbrella to bring these differences together. I think that one of the things that hurt all of us in the left is the fractured, isolated 
elements, you know? That is fighting over single-issue movements, and that's not an argument against single-issue movements, but I'll tell you what it's an argument against... No single-issue movement ever, ever produced a revolution. That's for sure! We need to firm these movements, and we need to bring them together. We need to understand their strengths, but also their limits, in terms of a comprehensive politics that's able to relate these movements and bring them together in an understanding of not only how they can produce, but also what it might mean to develop social movements in a politics that addresses all of this. The foundation that brings all of these movements to share in terms of the oppression that they've experienced.

I - You were just talking about revolution and, for some people, the concept of it is quite impossible. Still, we have some examples of real revolutions such as in Hungary, in Russia, in Cuba, and in Mexico... So, which kind of Revolution are you talking about?

HG - When I say Revolution, I mean a Revolution from the bottom. I mean a Revolution that takes radical change seriously, by virtue of the fact that it begins and ends with participatory involvement on the part of people in general and moves toward a radical restructuring of a corrupt society. Most Revolutions are led by vanguards; elitists who lead them... Maybe the word should be a radical change. Maybe the word should be going to the roots, maybe the word should be about making a fundamental change that doesn't just reform the existing kind of political systems in which we find ourselves. We need a radically different language, which suggests a structural and ideological change that is as comprehensive as is conceivably possible, right?

So, I guess I want to push it back a bit on the word. We need a fundamental restructuring; rooted in a sense of possibility that can imagine a future very different from the one we find ourselves in today. The beginning for that kind of political transformation would be not to equate democracy with capitalism, which might be the starting point. Democracy is not capitalism! It's not. And if we begin there, then we have to ask ourselves: What kind of foundation, what kind of structure, what kind of language, what kind of social relationships do we have to begin to imagine? I mean, I want to talk about radical change, rooted in the restructuring of the imagination. How could we reimagine hope so that we can imagine a future that doesn't represent the present - that is much better than the present? What kind of language do we want to use for that? Do we want to use Revolution? I think, we shouldn't. I believe you're right, I think that this word has a bad history. It scares people. But if we want to use "democratic change", "radically democratic change", we need to go to the root of the problem: a fundamental restructuring, right? Rooted in a sense of hope and possibility. Okay, if it is socialism, let's go with that.

I - In this case, what/how does socialism look like? Because just before we were discussing the possibility of socialism working nowadays...

HG - I mean, socialism begins with the assumption that everybody should operate under a set of economic, political, and social conditions that allow them to utilize their capacities for living in the world to the fullest extent possible. That means 
nobody should be poor; everybody should have access to quality health care, education, meaningful employment - all those areas that are essential to living a quality life. Socialism is the only ideology that raises serious questions about the need for human rights, that is, not only political and individual rights but also economic rights. For instance, it raises what does that mean about the economic system? And the political system? It means that we have to take social goods seriously, right? It means that we have to make sure that people are engaged. I mean, if we ask ourselves "What basically are the capacities that people have to have, to be able to be engaged, informed, and critical citizens?". Because we know in a radical way, in any democracy you can't have a democracy without informed citizens, it's not going to work. So, maybe the first issue is: to be informed, you need to be healthy. To be informed, you need to be educated. To be informed, you have to have social provisions, a social wage.

I - That's why the youth is so important!

HG - Yes, if you want to talk about the future, it is important to talk about what the future might mean for young people to prosper and not suffer. Socialism doesn't begin with the notion of a radical individual engaged in a cage fight with everybody else in which only one person is left on the island. Socialism begins with the notion of social justice, equality, and support for a viable notion of the social contract. It begins with the notion that nobody should ever be poor in the country, and people should have access to goods that matter, and that we need a political-economic system that expands the meaning of economic freedom through which one can have quality health care, a living wage, decent housing, a clean environment, and full quality education. I am not against a market economy, as long as it's controlled, as long as you're not paying CEO's twelve to thirteen million dollars a year. And as long as market values don't take priority over human needs. We don't need a market-driven society. We need a society driven by the principles of justice, equality, and freedom. It is necessary to make sure that equality works, you know? You have to have two things going on. One, you have to have public services that are available to people irrespectively of their wealth. And secondly, you have to make sure that that wealth is distributed not in the interest of relatively few people, but in the interest of society as a whole. So, socialism begins with a fundamental notion, and that notion is what do you do to make sure that you take the common good seriously? How do you protect notions of equality? How do you protect notions of justice? How do you protect notions of liberty? How do you basically develop a notion that freedom is not just freedom from interference, but also freedom to change the world? How can you participate in building that society? How do you move from what we call people participating in elections to people actually participating in exercising power? So, I'm not deeply concerned about a representative government, I'm concerned about a participatory government, like you said. That's a socialist idea!

I - The Brazilian neo-conservative right is pushing a political agenda to ensure control over our schools, so that only a "curriculum of facts", a "safer curriculum" is implemented, excluding any values and opinions. The ultra-right flag for education - School Without Parties - is just one example of the increasing 
movement toward conservative positions in Brazil, and the same is taking place in other countries. What would be some strategies for teachers and public intellectuals to confront such movements?

HG - I think that one of the things we need to recognize and make visible immediately is that any curriculum that organizes schools around facts and memorization is truly a call for a pedagogy of oppression. Because it's a pedagogy rooted in a form of anti-intellectualism, it's a form of pedagogy that is against critical dialogue, clearly a form of pedagogy that is about training and not educating, and it's a form of pedagogy that basically, at its best, wants to do everything it can to condition students to live in a world where all they have to do is memorize and not question. So, it's a pedagogy designed to depoliticize things, to kill the imagination. What Paulo [Freire] called "banking pedagogy". That's basically what it is.

And I think that what we need to really ask ourselves is what's the purpose of schools? Is the purpose of schools to depoliticize people, to make them stupid, and just memorize facts? To not theorize, to not think, to not be creative, to not use their imagination? Strategies such as the "School without Parties" are a pedagogical tool for an education for conformity, one that turns the school into a dead zone adaptation. This is an argument against the imagination. This ultra-right movement called "School without Parties" is a form of pedagogy that says that they hate the possibilities to get students to think, they hate the possibility of the students that could engage in thoughtful judgments. This is a pedagogy of thoughtlessness. Thoughtlessness, illiteracy, memorization... This is what characterizes a Fascist regime. Because the design basically turns schools into work stations that make students passive. So let's name them for who they are: they're factories for illiteracy. Schools without parties, it's just a metaphor for manufactured idiocy, which wages a war on civic culture, thinking, and the political imagination. It's an idiotic metaphor. All schools intervene in a particular way in deciding what facts are facts. What social experiences will be organized, what books will be used... There's no schooling without values, that's impossible! We're human beings! And not only that, it seems to me that as human beings, our lives are unfinished, right? As Paulo [Freire] said: "School is a model of direct involvement, because it's about the struggle over agency". All schools struggle over the question of what kind of future they want to give the students, all schools struggle over the question of what narratives they want to produce to shape the desires, the visions, the values, the respect for others, the respect for themselves, their relationship to others... No school escapes that! That's exactly what schooling is about. Schooling is an intervention in the kids' lives, into everybody's life. So, I mean, to say that school is neutral, to say that school is simply a book of recipes... To say that school is something like a machine that produces things, that spits out facts has to be the most oppressive, the most reactionary, and the most unproductive notion of schooling that one could possibly imagine. That's the pedagogy of oppression. That's pedagogy for creating a depoliticized notion of education that could only serve Fascists and authoritarian regimes.

I - What can teachers and students do to fight against it?

HG - They got to name it, first of all. They might address the latter question by first asking, "wait a minute, what are schools for?". I mean, I think what teachers 
have to do is fight for particular visions of schooling, right? If you want schools for informed citizens, if you believe school has something to do with democracy, you're not going to advocate an approach to schooling that just teaches facts. You're going to argue for a mode of education that makes knowledge meaningful in order to make it critical and transformative, one that actively engages their minds and emotions and gives them pedagogical lessons that are relevant, that draws from their communities, that gives them information they ordinarily wouldn't have, that allows them to debate and exchange, and push their imaginations to talk about issues that matter, to make it meaningful, to make it transformative, right? I mean, pedagogy should be about informing people, not about making them think they have nothing to do but memorize facts. When you advocate for that kind of pedagogy, you are clearly not just simply arguing for a particular form of pedagogy, you're arguing for a political system in which people are absent, they have no voices, they have been trained to be mute, unable to narrate themselves... That's a pedagogy that makes people voiceless in order to make them powerless. That's what that does.

I - You have written that education is not just related to economic and business interests any longer, but also, even more so, that education is the central mechanism to shape society to accept authoritarianism. Could you expand on your idea that a main space for political change, nowadays, is not in education, but in the cultural apparatus?

HG - I think what I value in many arguments from Antonio Gramsci to Louis Althusser to Raymond Williams is that consciousness matters, politics and culture matter, and that politics follows culture. Equally important is the notion that education is not limited to being produced in schools. We've often been told — and the left thinkers are particularly settable to this argument - that education and schooling are the same thing. And what we have failed to realize particularly with the new technologies and with the emergence of a whole range of cultural apparatuses, from digital to older forms of media, is that they have an enormous impact on educating people. And in neoliberal societies, they have an enormous impact on turning people into consumers, or commodities, and their central message is that the only obligation of citizenship is consumerism, with its endless rituals of shopping, buying and disposing of. Moreover, cultural apparatuses controlled by the rich and financial elite have an enormous impact on creating celebrity cultures that idolize idiocy, and literally make people dumb and stupid, you know? They have an enormous impact on producing forms of civic illiteracy, denying history, obliterating history. This is a thoughtless culture organized around the adoration of idols, you know, and celebrities, and personalities. This is a bighly individualized and illiterate culture that trades in fantasies of wealth and power.

And I think that there are two questions to be asked here: First, who controls the cultural apparatuses? I mean, if you have five companies controlling $95 \%$ of the culture of the apparatuses in the United States or Brazil? Most cultural apparatuses that define the mainstream press and media are very conservative, and are largely controlled by the conservative financial elite. These conservative apparatuses are basically teaching machines and work largely to undermine democracy, because they educate people to be stupid, and support people like Trump. They create models 
of civic illiteracy that fail to provide the knowledge and skills needed for informed citizens in a democracy. Such citizenship skills are necessary for thinking, developing informed judgments, and learning how to govern rather than be governed.

I mean, culture is the pre-condition for agency, culture is the symbolic medium through which we learn how we relate to ourselves, and others, and the larger world. At the same time, the cultural apparatuses that shape culture are enormously powerful pedagogical machines; they're dissemination machines without ethics. They shape desires, values, and we have to see them as central to any notion of politics. They have to be struggled over, they have to create alternative public spheres, we need to challenge what they say, and we need to do everything we can to make sure that they're not. I mean, these apparatuses, given how important they are, are now concentrated in the hands of relatively few people, but I think there's something else to be said. And I think what else has to be said is that this places new demands on education, meaning that we can't just educate students to be critical anymore; we've got to educate them to be cultural producers, they got to learn how to produce their own radio programs, they've got to learn how to narrate their concerns through diverse digital platforms, they've got to learn how to do television shows, they've got to learn about theater, they've had to become cultural producers because if not they might end up working in any one of the mainstream cultural apparatuses where they will have little control over either the conditions of their labor or the content of what is produced. Youth people, if they want to engage in crucial and significant forms of cultural production, have to be actively involved in creating diverse cultural spheres and media that range from theaters to schools to journalism, you know, that offer alternative points of view. This is worth repeating. Being critical is not enough. I mean, if they are going to take matters of agency and resistance seriously in an age of increasing domination, then people have got to learn how to be cultural producers; they got to learn how to read, they got to learn how to produce digital stations, digital media; they got to learn how to, you know, bring people together, they got to learn how to produce television shows, they got to learn how to do radio broadcast, this is really crucial. I mean the cultural realm offers very different options for resistance and education than what was available in the $20^{\text {th }}$ century, which was a century dominated by print culture.

I - Please, comment on the distinction between fascism and neo-fascism that is addressed in your recent work. Such distinction seems important to understand how polarized and violent our present society is in Brazil now. How do you perceive the role of the judicial system to legitimate these types of authoritarian governments?

HG - What I'm trying to do, first of all, the first thing to say is that fascism is not a static phenomenon, a historical relic, fixed in time in the 1930s, 40s, or 70s. Fascism appears in many forms, depending upon the society in which these previous Fascist forms reappear, for instance, the ultranationalism. The call for the strong man, the notion of racial cleansing, racial superiority, the hatred of intellectuals, the claim that culture is in decline, the notion that White people are under siege and are victims. These are all central elements of fascism, but they reappear in different forms, 
and I think the real question here is "How do we learn from the past? How do we recognize the ties these forms have with a lethal past?". Sometimes they're marginal, then they beginning to move to the center of society, you know? "What does it mean to understand the past so that we can recognize and learn from the past in terms of being able to recognize how fascist forms are reemerging, in a different historical moment, at the present time?". That's the question. So, rather than saying, for instance, "Well, we don't have concentration camps...". Well, we may not have concentration camps (though that may not be true given what is happening on the southern border of the United States with the proliferation of detention centers), but we have people being murdered, we have young children being separated at borders from their parents. And did we see that before? Was that a central element of a fascist politics? Even with sexual abuse! I mean, look, let's take Latin America. Where did we see democracy in exile? What is happening in Argentina? In Chile? In Peru? In Brazil? With the election of an ultra-right president and ruler by a demagogue certainly resonates with dangerous memories of a past dictatorship. How do we understand state violence in terms of what we saw in the past? What lessons do we learn here? One response might be: "Wait a minute, these are alarming signs that basically resonate with the past". The endpoint of that past was horrible and the ghosts that live in the past do not die, they simply resurface in different forms. Fascism is mobile, not static. We had concentration camps, we had dictatorships, we had cruelty being applied at the everyday life in millions of people. Do we want to reproduce it? Do we not want to recognize that these forms are emerging once again, place them in a historical context, and be able to say: "Okay, look, we're on the road to fascism here". You know, all the elements that I talked about earlier are reappearing again in different countries. They're appearing in Turkey, Brazil, Hungary, and they're also appearing in Poland, North Korea, they just choose a different language... They don't say: "It is fascism", they say: "It's a liberal democracy". Right? Or they say: "Who needs democracy when we need security? Freedom isn't about being able to do anything you want, freedom is freedom from fear!". Not having to worry about the left-wing in Brazil, you know? It's all coded language. And I think that what I'm saying about fascism is that: "Hey, look, all the elements that I see emerging in these societies, I've seen them before, and they're just taking different forms, that's all, but they have the same relevance, you know?". You put them all together and all of a sudden, at some point, you're in what Hannah Arendt called "dark times", and you really can't get out of it anymore. And we need to learn from the past and recognize how they imprint on the present or put it another way, we need to recognize these things; we need to name them when we see them. Authoritarianism comes in different forms, whether you want to talk about Stalin or you want to talk about, you know, what's happening in Poland, the United States... you know, but these forms of fascist politics that we see emerging now resonate very, very strongly with a past full-blown fascism.

I - And you've mentioned before that fascism is both outgrowth and exacerbated by global capitalism.

HG - First of all, I call it neoliberal fascism (Giroux, 2018), and my argument is that Neoliberalism has created such misery, such massive inequality, such mas- 
sive forms of human suffering that it mobilizes the passions of fascism. It mobilizes an ultra-national view. It mobilizes a hatred for the other. It mobilizes simplistic answers to our problems. It mobilizes the need for a strong man who's going to solve everything, right? It mobilizes hate and bigotry, which is easy, as it trades off the fears of people who are anxious, the people who are just basically racist, who want white nationalism, right? Or the people from the elite or middle class who just want security. It takes all those elements and puts them together, in a very bigoted kind of discourse that links the misery caused by casino capitalism and economic immiseration with an appeal to social cleansing. Now, the other side of this form of neoliberal fascism is what I call the legal illegality of violence. Meaning that, violence now increasingly becomes legalized. This refers to a form of state violence in which people disappear from the script of humanity; they are considered disposable. In this instance, justice becomes a tool of injustice turning the criminal justice system into an oppressive force for criminalizing and incarcerating people of color. The US is one of the largest jailers in the world. The justice system now, all of a sudden, uses the law against the law. It's the law of injustice, not the law of justice. The legal system becomes a tool of power for the privileged and a tool of oppression for those who are considered dangerous, excessive, and outside the bounds of the law.

I - Although they don't recognize it...

HG - Bullshit! Nah — it's not an objective system; it's a political system, right? And I think that what Fascist governments always do, to say the least, is they appoint people who basically support their ideologies, those judges that pass laws that are completely at odds with the notion of democracy... Completely at odds! And reinforce, like we see in Brazil, the judicial council or whatever it's called, passes a law that says Lula can't run for the presidency from prison; I mean, that's... Objective? $40 \%$ of the population chopped up charges? I mean, that's the legal system that's operating against democracy. In Brazil, the prosecutor and the judge handling the case worked together to frame Lula. That is not the working of a neutral judicial system; it is a judicial system that has become fascistic in its politics and shameless in its policies. This suggests that it is naive to assume that the legal system alone, in any country, could protect democracy, because a legal system can be used to undo democracy. And I think that actually one could go so far as to say that of all the pillars that we look at, that are central to any democracy and free plats, the judiciary system, higher public education, when that goes, it poses the greatest threat. Because, now, it legalizes injustice and oppression; and deaths; and violence. Because now, it means the legal system can make power unaccountable in the name of an illegal legality. That's a form of organized irresponsibility.

I - This week, we witnessed the fire that gutted the 200-year-old National Museum of Brazil, an immense loss to science, history, culture, and education. The museum, part of the Universidade Federal do Rio de Janeiro, had fallen into disrepair in recent years due to lack of funding. Last year, the Brazilian government amended the constitution, establishing a budgetary cap that is primarily impacting financial resources for education, culture and health. They put on hold all of the 
expenses for twenty years. Please comment on the long-term consequences of such neoliberalism policies, particularly on education and science.

HG - I have heard about it. My first reaction was... This is the political equivalent of barbarism, because it denies the richest part of what a society is... Its culture, its history, its contributions to the past, its intellectual life... these are the crucial registers of how a country defines itself, how it narrates its history, right? These are the narratives that keep alive a kind of vibrancy that can't be translated immediately into economic considerations. Tragedies of this sort are linked to one of the central elements of neoliberalism, which is the funding of short-term projects, at the expense of longterm projects, because short-term projects bring immediate returns, and long-term ones don't. In that formula, there is enormous collateral damage to young people, public goods, infrastructures, schools, libraries, and museums... All the things that add richness to a culture that cannot be defined solely in terms of the metrics of instrumentality, instrumentalism, or an immediate financial return. This is the choice between life and death; the people who make those choices in the interest of immediacy, these are the walking dead, the zombies, they hate democracy, and they hate the cultures and institutions that support it. And that's what this is an example of. As public goods fall into disrepair, a society loses its connection to the past, the embodiments of civic culture, and the dignity of investments in its future.

I - You are a Paulo Freire distinguished scholar in critical pedagogy at McMaster University. In your opinion, which are the main ideas and concepts of Paulo Freire's work that you think we should rescue and reinforce at universities?

HG - I think that one of the things that Paulo [Freire] alluded to was that education had to be on the side of justice; that education had to be concerned with questions of solidarity, that education was central to democracy, that it had to address the vulnerable, in society, and to be able to take on the burden of educating people who ordinarily wouldn't be included in education as the practice of freedom. I think that Paulo [Freire] was immensely in tune with the possibility that you could teach and learn at the same time, he was immensely alive to the richness of the imagination, the uncertainty, the pain of education, the willingness to take risks... He was aware of people who were not literate, in it. He was aware of the consequences of people not learning the skills necessary for reading the world and also what it meant if people could not use such skills to actively intervene in the world. For Paulo [Freire], literacy means teaching people how to be able to intervene in the societies in which they lived, he wanted to equip them with all those skills, all those forms of knowledge that were necessary to recognize that education was always about doing everything we could, to continue what it meant to educate people who were unfinished. Moreover, education never stopped at the door of the school, it took place in the field, it took place in farms, it took place in the media, you know? It was a central and ongoing element of society. The popular education! You know, that we had to address, because you can't talk about politics without talking about education, because you can't talk about politics without talking about consciousness. And you can't talk about intervening in the world, being an active citizen, or being practical, or, in any way, understanding the world without talking about what means to be informed. And Paulo 
[Freire] understood that, and that's why he was dangerous to the system. I mean, Paulo [Freire's] pedagogy was dangerous, because he said that you can't have education without an informed citizenry; you can't have it, a democracy without people who are educated, literate, and willing to take risks. He believed that education was central to every aspect of life, you know? We're constantly learning, we're constantly being bombarded by all these pedagogical messages coming from all kinds of diverse sides, and then, education is basically always a project, a political purpose, not a recipe. It's an ongoing project, you can't say: "here are ten things you need to know and that's it". It's unfinished, it's ongoing, it adapts to different circumstances, and it's diverse. It's historical, and I think that people who think that education is simple, pre-determined, also believe that education can take place without teachers, and that all one has to do is learn facts, memorize, and I think that what Paulo [Freire] was saying to people like that from the movement... without Parties is "That's not about education, that's about depoliticizing people and making them dumb - that is an education that denies agency and empties politics of any meaning". That's an authoritarian model of domination. That's an education for domination and not to decolonization. That is what he talked about as the pedagogy of the oppressed. When Paulo [Freire] Freire determined "pedagogy of the oppressed", what he was saying is that pedagogy can be about the facts and freedom, or it can be about the facts and domination, that there's no such thing as neutral education, it doesn't exist. That, in fact, what we need to ask here is: "Which side do you want to be on here?". What kind of students do you want? Do you want critically imaginative students who can eventually make up their own minds about their politics and regardless of what those politics are, at least be well informed? Paulo [Freire] was never telling people what their politics should be, Paulo [Freire] was saying, "look", and you must make a distinction between political and politicizing education. Politicizing education says: "Here's how you should think, here's what your ideology should be". It's pedagogy of indoctrination. He was completely against that! He was for political education, learning about power. Learning about the relationship between knowledge and power, learning about the struggle over the truth, learning about critical dialogue, learning everything you could to imagine how power could be used in every aspect of life through extended capacities. Paulo [Freire] wanted people to be individual critical agents and to be able to work collectively with others around shared concerns that would deepen them and make them more meaningful, the very notion of democracy itself.

I - You have worked with Paulo [Freire] for a long time, is there something about him that you would like to reinforce?

HG - Paulo [Freire] was the most humble...I mean, the thing about Paulo [Freire] that I always loved... was how humble he was. I've never met anybody with more humility. Paulo [Freire] never narrated himself; he never interviewed himself. He was sweet, he was lovely, he was fun to be around, he was warm... I mean, Paulo [Freire] would say things to me, like, in that Brazilian accent, he would say [changing the voice]: "Giroux... I don't believe in the radical, this is not me, I can't believe how can you be radical and what about you, don't you love to dance...". He was 
a romantic! You know? I mean... He was a man of poetry, he was a theologian. He was capacious in his interest and in his taste; he brought out the best in people. People loved him. I mean, you were immediately attracted to Paulo [Freire], he was a great story teller. I even remember him telling me when he was first arrested, he said: Giroux, they took me to their prison, and as I walked in, the guy said, we caught the canary. They put him in a cell next to somebody else. Elsa didn't know where he was... He said he was alone in this fight. There was a guy next door and he said his mother brought in a cooked chicken, and he said he could hear him eating the chicken, and the man said Paulo [Freire], I know who you are and he reached over and gave him something to eat. And these were the kinds of stories... I mean, Paulo [Freire] told me a long story about how he was working with some people somewhere when Castro called him on the phone, when the revolution had just began... Wanting him to come to Cuba (Chuckles).

I mean, this was Paulo [Freire]! I remember once he said: "Look, Giroux, the most important thing that ever happened to me, I got an honoree doctorate in Spain”. I said: "Really, Paulo [Freire]? That's fabulous". He said: "The Pope intervened and denied him the award (Laughs). He said: How great is that?" (More laughs). He was the most unorthodox leftist I've ever met, do you understand? He knew how to play. Too many on left today have lost the quality of playfulness. They can't play, you know? Except in Brazil, right, where they know how to play. People are often frozen, you know, in their orthodoxies. This was the opposite, for Paulo [Freire]. Paulo [Freire] was playful, humble, committed and always open to new possibilities. At the same time, he had firm convictions, but always open to dialogue, you know? And he never allowed himself to be treated like a hero. Never. He'd say: "No, no, no, this is about issues, not about me". He never... Angela Davis is like that, in the United States, right? People try to iconize her, she's like No, no, no, no, not about me! People often say to me: "You are the father of critical pedagogy", I say: "No, I'm not. That's nonsense! A lot of people talked about critical pedagogy, you know?". There was a movement for critical pedagogy; I'm not the father of anything. That's a terrible language. Because it seems to ignore the fact that we built our theories on the work of others, right? Collectively, this is a collective project, you know? I just write and publish a great deal (Giroux, 2011), people know about it, but to say I'm the father? I started it? That's nonsense, I don't like that language, you know, I don't think it helps anybody, and I think it erases histories. But Paulo [Freire] was just the sweetest, loveliest man. He would always ask you; he would say: "How is your wife? What a beautiful woman!". I mean, he was just sweet. Just lovely to be around; when you were with Paulo [Freire], it was like... it was like you were dancing with someone. You were eating and... whenever I was around Paulo [Freire], I felt we were drinking wine, we were talking about issues that mattered, we were touching each other, you know, it was... it was a very sensual, politically, uplifting event. I've met a lot of interesting people in my life, but man... Paulo Freire was special. He was special. I am trying to keep his legacy alive while also expanding my own work with some more contemporary challenges and new ideas, particularly around the emergent merging of neoliberalism, authoritarian populism, and fascism. 
I - Now, one final question. Do you think it would be possible to organize resistance forces in a global network to protect public interests against the fast rising of neoliberal fascism and ultra-right discourse? Are you aware of any initiative with this purpose?

HG - Look, the issue is no longer whether resistance is possible, it's a necessity. That's different. You're in the midst of a worldwide attack on democracies all over the world, including the most powerful country in the world, the United States, so the question is that this is absolutely a turning point in history that has to be performed; and I think we are seeing movements, I mean, we're seeing elements of; some of them start and they fail, but they started in Spain with the Podemos, though they no longer hold the torch of resistance, right? We see it in Portugal, you know? The successful use of the general strike in Hong Kong. We've seen movements... the Occupy Wall Street movement, the Anonymous, the Black Lives Matter movement... the Arab Spring... there a number of movements in the United States and all around the world. I mean, the environmental movement is massive all over the world now, because of the fact that the planet might not be here in ten years at this pace, right? There are a number of movements that I'm really appreciative of because they're movements that suggest developing the shared interest that cuts across borders in order to create an alliance among diverse movements. This is certainly true and has great possibilities for the ecological movement. That's important, right? Also, another potentially unifying movement that can weave together the threads of various movements include the anti-nuclear war movement. We need a strong movement against the possibility of a nuclear war, that's for sure.

But I think a third movement that has enormous possibilities is the movement against neoliberalism. We've never seen anything like neoliberalism in terms of its power and scope of oppression (Giroux, 2019). It's all across the world, right? It's not just centered in one or two places. I mean, this is a global movement, and it's done enormous damage all over the world, and I think increasingly you couple that with the intersections of race, class, gender, attacks on the women's reproductive rights, you know, attacks on social provisions and social welfare state, all of those things, and you get a rising neo-fascist movement as well... We have finally arrived at a point where you see the Black Lives Matter movement and other black movements in the United States, not only protesting police violence, but protesting state violence, and also now alliances with social movements in Latin Americans, Palestinians, and others, right. You see POC (People of Color) young students, young people walking out of schools protesting for what they call their struggle against the proliferation of guns in the United States, now they're talking about state violence; talking to the Black Lives movement students, Black Lives Matter Movement; you see teachers walking out of schools in the United States, and in some way they are following the model in Brazil, in which the unions are saying: "No, don't do it", and they're saying: "Sorry, we're doing it anyways". So, you see these various movements looking for new forms of political organization by which they could be both national and international, that really is very suggestive and ripe with possibilities for rethinking the nature of resistance on national and international levels. I think that now - I mean, even as I was reading today... even in Germany -, the rights of these neo-Nazi 
groups, they are now very public... Remember, every time these people appear, you get four times people who are against this stuff, because they are being pushed to the extremes. What's being said here is: Look, you can't turn away anymore! Now you get neo Nazis marching down your street, carrying flames torch lights like they did in Nazi Germany, shit, man! I mean, the choices are pretty stark. And I think we live in a time of stark choices. We live in a time in which people realize that you're either going to fight against this stuff or you're complicit with this whole thing... I mean, whether you're silent or whether you're actively involved with far right groups...

I - There's no neutrality? Is it true that to be neutral is impossible? HG - There's no neutrality, this is really serious...

I - Is that why you differentiate academics from public intellectuals?

HG - I am not sure they have to be different, but I do think many academics have retreated into specialism, crippling notions of professionalism, or in the case of tenured faculty, they have been seduced by the power of the neoliberal university. On the other hand, non-tenured faculty and those who make up part of the casual academic labor force occupy such precarious positions that it is very difficult for them to assume the role of being a public intellectual, given the real fear of their being fired and how few protections they have. What is clear is under the reign of the neoliberal university to be an academic today there is enormous pressure to believe that you don't have to be responsible to anything except your own interest. This separation of academic and public life means that faculty who believe this run the risk of becoming irrelevant politically and in many cases cannot even defend the very conditions of their own labor... Because if the university is under attack, I don't care if you're writing about something nobody cares about, your job's on the line! Even in terms of self-preservation, you've got to be able to defend the university as your public good. It is crucial for academics to say: "Look, you can't have a civilized society without universities, without public education, you can't do it!". The other side of this is that, you know, in the universities, academics have got to learn how to use the skills and tools that they have to not only write about their specialties, which is fine, but to even push the frontiers of theory further, no one's going to argue about that... but that's not all they can do. Academics have a responsibility to the public, to democracy, to justice to speak out, to let their voices be heard, to move people, to educate people, to say: "Hey, look, we have a choice, we can live in our specialties and live on our knees, or we can stand up and write about things that really matter today". It is crucial for educators to use their skills and knowledge to address important social problems. They need to take seriously the public side of their work. They also need to provide a model for young people who must be exposed to teachers who exhibit moral courage, believe in something, cause trouble and are willing to fight for what they believe in.

I - We want to thank you for your time and effort to address these questions, and to let you know that your answers will be extremely valuable to our staff and students at Brazilian universities that are facing the challenge of new authoritarianism. 


\section{REFERENCES}

ARONOWITZ, S.; GIROUX, H. Postmodern education: politics, culture, and social criticism. Minneapolis: University of Minnesota Press, 1991.

FREIRE, P.Pedagogy of the oppressed. $20^{\text {th }}$ ed. New York: The Continuum Publishing Corporation, 1983.

GIROUX, H. A. Teachers as intellectuals: toward a critical pedagogy of learning. Westport: Greenwood Publishing Group, 1988.

GIROUX, H. A. Border crossings: cultural workers and the politics of education. Abington: Routledge, 2007.

GIROUX, H. A. Youth in a suspect society: democracy or disposability? New York: Palgrave Macmillan, 2009.

GIROUX, H. A. On critical pedagogy. New York: Bloomsbury Publishing USA, 2011. GIROUX, H. A. Neoliberalism's war on higher education. Chicago: Haymarket Books, 2014.

GIROUX, H. A. Twilight of the social: resurgent politics in an age of disposability. Abington: Routledge, 2015.

GIROUX, H. A. American nightmare: facing the challenge of fascism. San Francisco: City Lights Books, 2018.

GIROUX, H. A. Terror of the unforeseen. Los Angeles: LARB Provocations, 2019. WILLIS, P. Learning to labour. London: Saxon House, 1977.

\section{ABOUT THE AUTHORS}

Gustavo de Oliveira Figueiredo has a doctorate in communication psychology: social interaction and human development from the Universitat Autónoma de Barcelona (Spain). He is a professor at the Universidade Federal do Rio de Janeiro (UFRJ).

E-mail: gfigueiredo.ufrj@gmail.com

Vera Helena Ferraz de Siqueira has a doctorate in education from the Columbia University (United States). She is a professor at the Universidade Federal do Rio de Janeiro (UFRJ).

E-mail: verahf@yahoo.com.br

Received on September 11, 2019

Approved on March 03, 2020 